\title{
The Role of Presenting Exclusive Breastfeeding for The Prevention of Stunting Based on The Culture of Tudang Sipulung
}

\author{
Andi Elis*, Rohani Mustari, Marlina \\ Faculty of Nursing Universitas Indonesia Timur, Indonesia \\ *andielis1324@gmail.com
}

\begin{abstract}
The prevalence of stunting in Indonesia is increasing. The efforts to prevent stunting can be done by giving exclusive breastfeeding. This study aims to identify and assess changes in knowledge, attitudes and actions of mothers in exclusive breastfeeding for prevention of stunting before and after health education interventions based on Tudang Sipulung in the treatment group and the control group at Puskesmas Jumpandang Baru and Puskesmas Pattingaloang Makassar in 2020. The type of this research is "Quasy Experiment", pre-test and post-test with control group design. The sample in this study was divided into two groups. The instruments are questionnaires and leaflets. The data were analyzed using the Mann Whitney $U$ test. the test result $(\mathrm{p}=0.011)$ on knowledge. The result of the postpartum mother's attitude $(\mathrm{p}=0.000)$ and the post-partum mother's actions showed the result $(\mathrm{p}=0.000)$. There is an effect of-based health education interventions Tudang Sipulung.
\end{abstract}

Keywords: Exclusive Breastfeeding, Stunting, Tudang Sipulung 


\section{STRADA Jurnal Ilmiah Kesehatan}

DOI: $10.30994 /$ sjik.v9i2.461

ISSN: 2252-3847 (print); 2614-350X (online)

Vol.9 No.2 November 2020 Page.1230-1237

\section{BACKGROUND}

Nutritional state or nutritional status is a picture of what is consumed over a long period of time. The state of nutrition can be in the form of malnutrition, good or normal or over nutrition. One of the health problems in children is related to growth due to insufficient nutritional intake that can lead to stunting (Pangkong et al., 2017). Stunting is a major cause of morbidity among children under five. Knowledge of risk factors for stunting is an important prerequisite for developing and strengthening nutrition intervention strategies(Fikadu et al., 2014). continued breastfeeding for at least 1 year was found to be associated with stunting childhood (Nsereko et al., 2018).

In 2012, WHO set a global target to reduce the number of stunted children by $40 \%$ from a baseline of 171 million in 2010 to 100 million by 2025(Hagos et al., 2017). Stunting is caused by two factors, namely direct and indirect. One of the direct causes of stunting is exclusive breastfeeding (Pangkong et al., 2017).

Based on the results of research by Sri Indrawati (2017) entitled the relationship of exclusive breastfeeding with the incidence of stunting in children aged 2-3 years. The results showed that there was a relationship between exclusive breastfeeding and the incidence of stunting aged in children2-3 years with a p-value $(0.000>0.05)$ (Indrawati, 2017).

Riskesdas data shows, the number of problems stunting in children under five in 2007 was $36.8 \%$ very short and short, in 2013 with a very short and short proportion of $37.8 \%$, and in 2018 with a proportion of $30.8 \%$. But by looking at the nutritional status of the short course is increasing from year to year is the year 2007 with $18.0 \%$, in 2013 the amount of $19.2 \%$ and in 2018 reached 19.36 (Kesehatan et al., 2018).

Data from the Makassar City Health Office, the number of stunting in 2018 was $8.75 \%$ and in 2019 the number of stunting was $8.61 \%$. Although the number of stunting in Makassar City has decreased, it is not a significant decrease. Meanwhile, in 2018, the exclusive breastfeeding coverage for Makassar City was $79 \%$ and in 2019 it was $79.1 \%$.

Meanwhile, the stunting data at the Puskesmas Jumpandang Baru in 2018 was $4.6 \%$ and in 2019 was $4 \%$. The number of stunting at Puskesmas Pattingaloang was $6.4 \%$ in 2018 and in 2019 it was $8.2 \%$. Based on the results of these data, it shows that there is an increase in the number of stunting at Puskesmas Paattingaloang. Meanwhile, the coverage of exclusive breastfeeding in the Puskesmas Pattingaloang work area was $74 \%$ in 2018 and in 2019 it was 58.33\%. At the Puskesmas Jumpandang Baru, the coverage of Exclusive breastfeeding was $80.5 \%$ in 2018 and in 2019 it was $78.8 \%$.

It can be seen that the exclusive breastfeeding coverage at the two health centers has decreased and is still far from the national exclusive breastfeeding coverage rate of $80 \%$. Lack of public knowledge, especially postpartum mothers, about the importance of exclusive breastfeeding makes exclusive breastfeeding not run smoothly.

Ways to increase the knowledge, attitudes and actions of mothers in exclusive breastfeeding need to be given health education, where health education aims to increase public knowledge and awareness to maintain and improve their own health. Related to that, health education can be used as an effort to change a mother's behavior in giving exclusive breastfeeding to her child, besides providing education on how to care for breasts through breast care practices carried out by breastfeeding counselors can increase the mother's knowledge in breast care so that there is readiness to provide Breastfeeding to the baby for no reason because the breast is not ready for breastfeeding and with breast care has been shown to have an effect on milk production. Providing health education will be much more effective when using media aids in the form of leaflets to understand the 


\section{STRADA Jurnal Ilmiah Kesehatan}

DOI: $10.30994 /$ sjik.v9i2.461

ISSN: 2252-3847 (print); 2614-350X (online)

Vol.9 No.2 November 2020 Page.1230-1237

material presented compared to the method of lecturing without media (Soekidjo Notoadmodjo, 2010).

In accordance with the culture in South Sulawesi, health education is carried out on the based of Tudang Sipulung, namely sitting together to discuss things that are considered important, sharing information, experience and knowledge, so that postpartum mothers will find it easier to understand the importance of exclusive breastfeeding(Nuh, 2016). If this is done, it can reduce the prevalence of stunting in children under five.

Based on this, to find out the behavior of post-partum mothers towards the role of exclusive breastfeeding in preventing stunting, the researchers wrote the title The Role of Exclusive Breastfeeding for the Prevention of Stunting based on the Tudang Sipulung Culture at Puskesmas Jumpandang Baru and Puskesmas Pattingaloang Makassar.

\section{METHODS}

The research design used "Quasy Experiment", namely pre-test and post-test with control group design ( $S$ Notoadmodjo, 2010). The population in this study were postpartum mothers at Puskesmas Jumpandang Baru and Puskesmas Pattingaloang Makassar City. The sample size in this study used the sample size formula (n) analytical categorical-numerical pairwise research. Sampling was carried out by purposive sampling with a total sample of 60 postpartum mothers (30 treatment group respondents, 30 control group respondents. The instruments in this study were questionnaires and leaflets.

The bivariate analysis was carried out on two variables that were suspected to be related or correlated ${ }^{9}$ This analysis done to address the hypothesis that has been formulated is to know the effect of the intervention health education based Tudang Sipulung to the increase of knowledge, attitudes and actions postpartum mothers in exclusive breastfeeding for prevention of stunting. Before the bivariate analysis conducted prior normality test of Shapiro-Wilk.the test results The normality of the data shows that the $p$ value for all variables is less than 0.05 , so it can be concluded that the data for all variables are not normally distributed. For the knowledge, attitudes and actions of postpartum mothers giving exclusive breastfeeding for the prevention of stunting can use thetest Mann Whitney U.

\section{RESULTS}

Table 1. Characteristics of Respondents

\begin{tabular}{|c|c|c|c|c|c|}
\hline \multirow[t]{3}{*}{ Characteristics } & \multicolumn{4}{|c|}{ Group of Respondents } & \multirow{3}{*}{$\begin{array}{c}P \\
\text { Value }\end{array}$} \\
\hline & \multicolumn{2}{|c|}{ Treatment } & \multicolumn{2}{|c|}{ Control } & \\
\hline & $\mathbf{n}$ & $\%$ & $\mathbf{n}$ & $\%$ & \\
\hline \multicolumn{6}{|l|}{ Mother's Age } \\
\hline$<18$ years & 2 & 6.67 & 2 & 6.67 & \\
\hline $19-25$ years & 7 & 23.33 & 7 & 23.33 & 1,000 \\
\hline 26-30 years & 8 & 26.67 & 8 & 26.67 & \\
\hline$>30$ years & 13 & 43.33 & 13 & 43.33 & \\
\hline \multicolumn{6}{|l|}{ Education } \\
\hline Low (didn’t SD, SD, SLTP) & 14 & 46.67 & 10 & 33.33 & 0,215 \\
\hline High (High School,University) & 16 & 53.33 & 20 & 66.67 & \\
\hline \multicolumn{6}{|l|}{ Profession } \\
\hline IRT & 22 & 73.33 & 22 & 73.33 & \\
\hline Self-employed & 4 & 13.33 & 4 & 13.33 & 1,000 \\
\hline Private employees & 4 & 13.33 & 4 & 13.33 & \\
\hline \multicolumn{6}{|l|}{ Number of Children } \\
\hline $1-2$ & 14 & 46.67 & 14 & 46.67 & \\
\hline
\end{tabular}




\section{STRADA Jurnal Ilmiah Kesehatan}

DOI: $10.30994 /$ sjik.v9i2.461

ISSN: 2252-3847 (print); 2614-350X (online)

Vol.9 No.2 November 2020 Page.1230-1237

\begin{tabular}{lrrrrr}
\hline 3-4 & 10 & 33.33 & 10 & 33.33 & 1,000 \\
$>5$ & 6 & 20.00 & 6 & 20.00 & \\
\hline Income & & & & & \\
<UMK ( $\leq$ Rp.3.000.000) & 13 & 43.33 & 25 & 83.33 & 0,001 \\
>UMK (> Rp.3.000.000) & 17 & 56.67 & 5 & 16.67 & \\
\hline Data Source: Primary data, 2020 & & & &
\end{tabular}

Table 1 shows that there is no significant difference between the treatment and control groups when viewed from the age of the mother $(p=1,000)$, education $(p=0.215)$, occupation $(p=1,000)$ and the number of children $(p=1,000)$, except that there is a difference in income. which is significant $(p=0.001)$.

Table 2. The Effect of Health Education Based on Tudang Sipulung on Maternal Knowledge in Giving Exclusive Breastfeeding for Stunting Prevention

\begin{tabular}{cccc}
\hline & \multicolumn{2}{c}{ Group } & \\
\cline { 2 - 3 } Time & Treatment & Control & P \\
\cline { 2 - 3 } test & $($ Mean, \pm SD) & $($ Mean, \pm SD) & value \\
\hline Pre Test & $7.86 \pm 1.502$ & $8.13 \pm 1.995$ & 0.346 \\
Post test & $10.50 \pm 0.973$ & $9.40 \pm 1.693$ & 0.011 \\
\hline
\end{tabular}

Data Source: Primary data, 2020

Table 2 shows that the mean pre test in the treatment group (7.86) and the control group $(8.13)$ is statistically no significant difference $(\mathrm{p}=0.346)$. While the mean post test value in the treatment group (10.50) and the control group (9.40) was significantly different $p=0.011<0.05$. Therefore, it can be concluded that there is an effect of-based health education Tudang Sipulung on maternal knowledge in providing exclusive breastfeeding for stunting prevention. The regression test results show that knowledge is not influenced by the mother's age, education, occupation and number of children.

Table 3. The Effect of Health Education Based on Tudang Sipulung on Maternal Attitudes in Giving Exclusive Breastfeeding for Stunting Prevention

\begin{tabular}{|c|c|c|c|}
\hline \multirow{3}{*}{$\begin{array}{c}\text { Time } \\
\text { test } \\
\end{array}$} & \multicolumn{2}{|c|}{ Group } & \multirow{3}{*}{$\begin{array}{c}P \\
\text { value } \\
\end{array}$} \\
\hline & Treatment & Control & \\
\hline & $($ Mean, \pm SD $)$ & $($ Mean, \pm SD $)$ & \\
\hline Pre Test & $6.63 \pm 1.188$ & $6.83 \pm 0.833$ & 0.413 \\
\hline Post test & $9.03 \pm 0.764$ & $7.73 \pm 0.944$ & 0.000 \\
\hline
\end{tabular}

Data Source: Primary Data, 2020

Table 3 shows that the mean pre-test value in the treatment group (6.63) and the control group $(6.83)$ is statistically no significant difference $(p=0.413)$. While the mean post test value in the treatment group (9.03) and the mean post test value in the control group (7.73), statistically there is a significant difference $p=0.000<0.05$. So that there is an educational effect of the cultural group Tudang Sipulung on mothers' attitudes in giving exclusive breastfeeding to prevent stunting. The regression test results show that attitudes are not influenced by mother's age, education, occupation and number of children. 
STRADA Jurnal Ilmiah Kesehatan

DOI: $10.30994 /$ sjik.v9i2.461

ISSN: 2252-3847 (print); 2614-350X (online)

Vol.9 No.2 November 2020 Page.1230-1237

Table 4. The Effect of Health Education of Tudang Sipulung on Maternal actions in Giving Exclusive Breastfeeding for Stunting Prevention

\begin{tabular}{cccc} 
& \multicolumn{2}{c}{ Group } & \\
\cline { 2 - 3 } Time & Treatment & $\boldsymbol{P}$ \\
\cline { 2 - 3 } test & (Mean, \pm SD) & Control & value \\
\hline Pre Test & $3.83 \pm 0.647$ & (Mean, \pm SD) & 0.048 \\
Post test & $5.56 \pm 0.504$ & $4.23 \pm 0.817$ & 0.000 \\
\hline
\end{tabular}

Data Source: Primary Data, 2020

Table 4 shows that the mean pre test value in the treatment group (3.83) and the control group (4.23) is statistically significant $(\mathrm{p}=0.048)$. While the mean post test value in the treatment group (5.56) and the mean post test value in the control group (4.70), statistically there is also a significant difference in the post test. $p=0.000<0.05$. So that there is an effect of the education of the cultural group Tudang Sipulung on the actions of mothers in providing exclusive breastfeeding for stunting prevention. Furthermore, the results of the regression test showed that the action was not influenced by the mother's age, education, occupation and number of children.

\section{DISCUSSION}

The results of this study indicate that there is a difference in knowledge before and after the intervention, as well as a significant difference between before and after being given tudang sipulung culture-based group education in the treatment group and the control group $(p$ value $=0.011)$, which proves that there is an effect of education. Culturebased health of tudang sipulung to the knowledge of postpartum mothers in giving exclusive breastfeeding for prevention stunting. The results of this study are in line with the research by Shalaby et al (2019) conducted at King Fahd Armed Forces Hospital showing that there is an effect of health education on maternal knowledge in giving exclusive breastfeeding, seen from the results there is an increase from $163(70 \%)$ to 213 $(91 \%)$ mother's knowledge with $(p$ value $=0.009)$ (Shalaby et al., 2019). The main obstacle to exclusive breastfeeding is the mother's lack of knowledge about exclusive breastfeeding, breast care methods, and proper breastfeeding. Mother's knowledge about proper breastfeeding and the benefits of breastfeeding will support the success of breastfeeding (Damayanti et al., 2017). According to research conducted by Sholeha et al (2019), it shows that one of the results of health education by carrying out breast care in postpartum mothers can affect breast milk production $(p=0.002)$ (Sholeha et al., 2019).

In Murdaugh at.al 2019 says that according to the Health Promotion Model in the process of providing health education there is a change in behavior in terms of knowledge, one's attitude, commitment to action is also influenced by interpersonal factors, the benefits of action, action barriers, self-efficacy and attitudes of mothers in giving activities Exclusive breastfeeding (Aswitami, 2019).

Furthermore, the results showed that there were differences in attitudes before and after the intervention. Likewise, there were significant differences between before and after being given education based on tudang sipulung culture in the treatment group and the control group $(P$ value $=0.000)$. proven by the value of the statistical test, it means that there is an effect of Tudang Sipulung based health education on the mother's attitude in giving exclusive breastfeeding to prevent stunting. This research is in line with research by Ernawati et. Al (2016) shows that there is a significant difference in the average attitude 


\section{STRADA Jurnal Ilmiah Kesehatan}

DOI: $10.30994 /$ sjik.v9i2.461

ISSN: 2252-3847 (print); 2614-350X (online)

Vol.9 No.2 November 2020 Page.1230-1237

between the intervention group and the control group $(P$ value $=0.000)$ (Ernawati \& Tahlil, 2016).

In accordance with the intervention in this study, health education based on Tudang Sipulung is carried out which can help post-partum mothers in determining attitudes towards exclusive breastfeeding behavior because in Tudang Sipulung-based health education using methods and media such as leaflet media or just counseling with the lecture method facilitates knowledge change. The attitudes and actions of mothers in giving exclusive breastfeeding are because in education based on tudang sipulung, there is mutual support, sharing of information, experience and knowledge among members of tudang sipulug (Nuh, 2016). So that the implementation of these activities can help reduce the prevalence of stunting in toddlers. This research is also supported by research by Sitorus (2020), namely the Health Promotion of exclusive breastfeeding on knowledge and attitudes of pregnant women, with the results of the research that there is an effect of health promotion on maternal attitudes about exclusive breastfeeding in preventing stunting before and after health promotion (Sitorus \& Silalahi, 2020).

Furthermore, the results of this study indicate that there are differences in the actions before and after the intervention. Likewise, there are significant differences between before and after being given education based on the culture of tudang sipulung groups in the treatment group and the control group ( $p$ value $=0.000)$. This study is in line with the research conducted by Lanyumba et.al (2019) in Balantak Sub-district, Luwuk Banggai, with the results of the study that there is a significant influence on the actions of mothers under five before and after being given exclusive breastfeeding counseling, where the statistical test is $(p<0.05)$ (Lanyumba et al., 2019).

Changes in action are a tangible result of changes in the knowledge and attitudes of postpartum mothers in giving exclusive breastfeeding in an effort to prevent stunting (Yuliana et al., 2019). All aspects of knowledge, attitudes and actions will shape one's behavior. Mother's knowledge about breastfeeding can increase one's awareness, which will then lead to a positive attitude and will be followed by a commitment to change and will be able to adopt better actions so as to give birth to new behaviors and the expected outcomes with new behaviors in exclusive breastfeeding can reduce the prevalence of stunting. This is supported by a statement from Green \& Kreuter (2000) which explains that behavior change occurs not instantaneously but is carried out through stages of cognitive change, then changes in attitude and after appreciation, changes in action occur. Thus, based on the results of the research and the theory described, the hypothesis which states that health education based of Tudang Sipulung affects the knowledge, attitudes and actions of postpartum mothers in giving exclusive breastfeeding for prevention stunting is acceptable.

\section{CONCLUSION}

There is an effect of Tudang Sipulung culture-based health education on the knowledge, attitudes and actions of postpartum mothers in providing exclusive breastfeeding for the prevention of stunting before and after the intervention in the treatment and control groups. It is hoped that in the future health education activities based on local culture will be carried out continuously in the working area of the Puskesmas Jumpandang Baru and the Puskesmas Pattingaloang so that postpartum mothers have a strong desire to provide exclusive breastfeeding as an effort to prevent stunting. 


\section{STRADA Jurnal Ilmiah Kesehatan}

DOI: $10.30994 /$ sjik.v9i2.461

ISSN: 2252-3847 (print); 2614-350X (online)

Vol.9 No.2 November 2020 Page.1230-1237

\section{REFERENCES}

Aswitami, N. G. A. P. (2019). Efektivitas Edukasi ASI Eksklusif Terhadap Pengetahuan dan Pemberian ASI Eksklusif Pada Ibu Nifas. Journal Center of Research Publication in Midwifery and Nursing, 3(2), 40-45. https://doi.org/10.36474/caring.v3i2.132

Damayanti, R. A., Muniroh, L., \& Farapti, F. (2017). Perbedaan Tingkat Kecukupan Zat Gizi dan Riwayat Pemberian Asi Eksklusif pada Balita Stunting dan Non Stunting. Media Gizi Indonesia, 11(1), 61-69. http://dx.doi.org/10.20473/mgi.v11i1.61-69

Ernawati, B., \& Tahlil, T. (2016). Peningkatan Pengetahuan, Sikap dan Tindakan Ibu dalam Memberikan ASI Eksklusif Melalui Edukasi Kelompok. Jurnal Ilmu Keperawatan, 4(2).

Fikadu, T., Assegid, S., \& Dube, L. (2014). Factors associated with stunting among children of age 24 to 59 months in Meskan district, Gurage Zone, South Ethiopia: a case-control study. BMC Public Health, 14(1), 800.

Hagos, S., Hailemariam, D., WoldeHanna, T., \& Lindtjørn, B. (2017). Spatial heterogeneity and risk factors for stunting among children under age five in Ethiopia: A Bayesian geo-statistical model. PloS One, 12(2), e0170785. https://doi.org/10.1371/journal.pone.0170785

Indrawati, S. (2017). Hubungan Pemberian Asi Esklusif dengan Kejadian Stunting pada Anak Usia 2-3 Tahun di Desa Karangrejek Wonosari Gunungkidul. Universitas' Aisyiyah Yogyakarta.

Kesehatan, K., Penelitian, B., \& Kesehatan, P. (2018). Hasil Utama RISKESDAS 2018. Jakarta [ID]: Balitbangkes Kementerian Kesehatan.

Lanyumba, F. S., Dianomo, E., Ebu, Z. Y., Yalisi, R., \& Sattu, M. (2019). pengaruh Penyuluhan Asi Eksklusif terhadap Pengetahuan, Sikap dan Tindakan Ibu Balita di Kecamatan Balantak Selatan Kabupaten Banggai: The Effect Of Exclusive breastfeeding Counseling On Knowledge, Attitude And Action Of Mother's Toddler In Balantak Selat. Jurnal Kesmas Untika Luwuk: Public Health Journal, 10(2), 5761.

Notoadmodjo, S. (2010). Metodologi Penelitian Kesehatan, hal 115-130. Jakarta, PT Rineka Cipta.

Notoadmodjo, Soekidjo. (2010). Promosi Kesehatan Teori \& Perilaku. Jakarta: Rineka Cipta, 275.

Nsereko, E., Mukabutera, A., Iyakaremye, D., Umwungerimwiza, Y. D., Mbarushimana, V., \& Nzayirambaho, M. (2018). Early feeding practices and stunting in Rwandan children: a cross-sectional study from the 2010 Rwanda demographic and health survey. Pan African Medical Journal, 29(1), 1-6.

Nuh, M. S. (2016). Tudang Sipulung: A Conflict Resolution Wisdom of Bugis-Makassar Community. Hasanuddin Law Review, 1(2), 241-249. http://dx.doi.org/10.20956/halrev.v1i2.308

Pangkong, M., Rattu, A. J. M., \& Malonda, N. S. H. (2017). Hubungan antara Pemberian ASI Eksklusif dengan Kejadian Stunting pada Anak Usia 13-36 Bulan di Wilayah Kerja Puskesmas Sonder. KESMAS, 6(3).

Shalaby, H., Obaid, R. A., Alharthi, R. H., Barayan, M. M., Bagabas, N. S., Battarjee, R. M., Baroom, N. A., \& Tallab, M. A. (2019). Health education role in promoting mothers' beliefs, knowledge and practice of exclusive breastfeeding among King Fahd Armed Forces Hospital population. Int J Community Med Public Health, 6, 1853-1862. http://dx.doi.org/10.18203/2394-6040.ijcmph20191615 


\section{STRADA Jurnal Ilmiah Kesehatan}

DOI: $10.30994 /$ sjik.v9i2.461

ISSN: 2252-3847 (print); 2614-350X (online)

Vol.9 No.2 November 2020 Page.1230-1237

Sholeha, S. N., Sucipto, E., \& Izah, N. (2019). Pengaruh Perawatan Payudara Terhadap Produksi ASI Ibu Nifas. Oksitosin: Jurnal Ilmiah Kebidanan, 6(2), 98-106. https://doi.org/10.35316/oksitosin.v6i2.491

Sitorus, R. S., \& Silalahi, K. L. (2020). Promosi Kesehatan tentang Pemberian Asi Eksklusif terhadap Pengetahuan dan Sikap Ibu Hamil. Jurnal Keperawatan Priority, 3(1), 23-29. https://doi.org/10.34012/jukep.v3i1.801

Yuliana, W., ST, S., Keb, M., \& Hakim, B. N. (2019). Darurat stunting dengan melibatkan keluarga. Yayasan Ahmar Cendekia Indonesia. 